\title{
Philip Greene: 'In order to be a good dentist you must be a good periodontist'
}

Please send any ideas for feature articles for consideration to:

Ruth Doherty,

Managing Editor,

British Dental Journal

The Macmillan Building,

4-6 Crinan Street,

London,

N1 9XW

Email: r.doherty@nature.com

British Society of Periodontology President Philip Greene discusses the considerable changes in periodontics over the past 40 years and suggests that the reward system for GDPs must change to allow the delivery of effective perio for patients.

\section{What attracted you to specialise in periodontics?}

I left the University of Liverpool understanding that periodontics was the most fundamental element of dentistry. At that stage all I wanted was to be the best dentist I could possibly be. I realised I had to be good at perio to do that because the gums are part of the body's general milieu and the gateway to the supporting structures of the teeth. If you are going to restore the teeth and keep them there long term, they need to be firmly supported. This was the era with the birth of preventive dentistry and people like Marsh Midda (ex-President of the BSP), Colin Dexter and Brian Lux were giving impressive talks on the topic. So I believed, and still do, that in order to be a good dentist you must be a good periodontist. Generally, I think that this is not fully understood...even now.

I was lucky to start off in practice with Phil Wander and Alan Dobkin in Manchester. They let me do more or less what I wanted to do irrespective of whether it was profitable for them in the practice. After I had been working with them for a short time they took me to a meeting at which the speaker was John Zamet. He was the first periodontist to set up a specialist practice in the UK. This was in the early 1970s and he had been in part-time specialist practice in London for a few years by then. He showed me that it was possible to

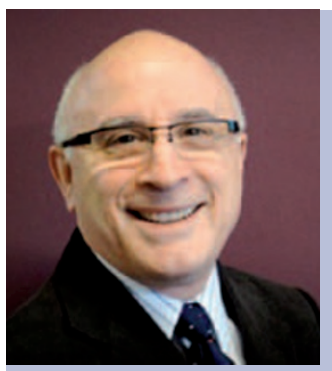

Philip Greene has over forty years of experience in general and specialist periodontics practice. He qualified from the University of Liverpool in 1971 and, after a post as a house officer in the Liverpool Dental Hospital, began work in general dental practice. He was awarded the Fellowship in Dental Surgery from the Royal College of Surgeons of Glasgow in 1980 and was accepted on the General Dental Council's specialist list in periodontics when it was established in 1998. Philip has published many papers and articles on periodontics and related subjects. His video entitled Initial periodontal therapy, was awarded the Diplome d'Honneur at the 1991 International Dental Film and Video Festival in Paris. He is a co-author of the chapter on periodontics in the Clinical textbook of dental hygiene and therapy, first published in 2006 and now in its second edition. Philip is a fully trained and active dental expert witness, and was a founding member of the Expert Witness Institute. He was also the founding Chairman of the Dental Practitioners Section of the British Society of Periodontology (BSP) and currently serving as President of that society.

specialise in periodontics and get really good at it in order to provide a service both to the profession and to patients. I spent a day at his practice in London after which my course was set: I wanted to end up as a specialist in perio in Manchester. So I knew exactly where I wanted to go, which is tremendous help when you're building a career.

\section{What are the main changes in the field of periodontics since you began in practice?}

The aetiology of the disease hasn't really changed but our confidence in treating it has changed dramatically. When I qualified we thought that if you removed all the plaque and calculus the gums would probably get better, but there was an element of unpredictability about it. Also ultrasonic units were only in the very early stages. Now we know that, most of the time, we can treat most periodontitis non-surgically and effectively. So the amount of surgery required is greatly reduced from what it used to be. This has been a major change.

We now understand much more about the importance of specific bacteria in the development of periodontal disease and the importance of the patients' immune response to the disease. We know more about risk factors - smoking, diabetes, stress - and how they impact on a patient's disease. So we understand periodontitis a lot better than when I first qualified, even though we may not understand it on the immunological level as deeply as we might like.

Another big change in periodontal practice is that when I qualified it was simply impossible to regenerate bone that had been lost due to periodontal disease; now it is possible. There are many 
circumstances in which we can actually regenerate some of the tissues which have been lost. This was a holy grail when I qualified and now it's a routine procedure in practice.

We have also become much more adept at plastic surgery procedures. We can correct recession defects and give patients stronger gum tissue in areas where it is weak or deficient. This can make a big difference to patients. People are sometimes born with very little attached gingiva around the teeth and we can correct that now much better than we did before.

Another big change in periodontics is that we are beginning to see some evidence that there are interconnections between periodontal disease and other diseases. Once the teeth are formed they are fairly inert for the most part and don't have any effect on the patient's whole body. However, if the patient has a large amount of inflammation in the mouth due to periodontal disease this will have an impact on the rest of the body. Chemicals produced by the inflamed tissues will spread around the body and those inflammatory markers can affect the other tissues in the body. We don't fully understand it yet, and the connection is stronger for some conditions than others, but there is certainly some interaction going on that we didn't appreciate before. The link is the strongest with diabetes where we think that periodontitis can increase the risk of getting diabetes. We know that patients' glycaemic control can be affected by inflammation in the mouth. So if a patient has poor glycaemic control and you treat the periodontitis, their glycaemic control improves and vice versa.

\section{Do you envisage changes in practice because periodontal disease is now being linked to other diseases?}

It might make us interact differently with the rest of the medical profession and our patients. We could all be asking patients a little bit more about their family history of diabetes and cardiovascular disease with the suggestion that, if they have a high level of periodontitis, we might say to them that treating their perio problems could decrease their risk of cardiovascular disease or diabetes.

We know that smoking is a major issue for periodontal disease which we didn't understand fully when I qualified. Smokers have much more gum disease than non-smokers and the results of their treatment are noticeably poorer. Though we do still treat smokers, treatment can be 50\% less effective for smokers than for non-smokers. If they stop smoking treatment results improve and eventually the risk levels for periodontitis come back to normal.

\section{What are your views on CPD for dentists?}

It is essential and should have been mandatory a long time ago. It is a pity that it has to be compulsory but human nature being what it is means it's a necessity. In my earliest days in dentistry I was involved in the 'Dental Postgraduate Society' in Manchester, set up by Hans Kurer, Tony Kravitz, Mike Rich and other local practitioners. Back in the 1970s this group was organising international postgraduate courses and bringing world-class clinicians to the UK to give courses - people like Henry Goldman and Herb Schilder. We were pioneers of postgraduate education in UK dentistry really.

\section{What are the main challenges you have found in dental practice?}

In my early days the challenges were related to trying to do the quality of dentistry that I wanted to do while working in a restricted NHS system. I was passionate and I was introduced to postgraduate education by people who inspired me to go to courses and listen to the best in the world. Once you've tasted from that well you don't want to go back and do basic dentistry anymore. You want to go and do it as best you can, and that is demanding. When I had my own practice I had to make some compromises to do that. It's also a challenge just taking care of people, especially when they are anxious and stressed. It's a challenge running a business in a healthcare profession especially when you are working under a system that restricts the fees. Although I did the best I could on the NHS I wanted to do better and eventually I had to leave the system.
It was a challenge establishing a speciality. Having realised I wanted to specialise, John Zamet advised me to go to London and do a masters degree in perio because there were no specialised training programmes in those days. But I didn't want to move to London as we had a small baby at that time and I didn't want to uproot my family. Thus, he suggested that I get a fellowship instead. At that time if you want to be a specialist you had to put yourself on the same level as the consultants in the hospital. So I got myself on the hospital house officers' course, passed my fellowship exams and started a specialist practice in 1981. There was no such thing then as a specialist practice outside of London. I built up my specialist practice very gradually - half a day a week. At first, I asked my colleagues and friends to send any tricky perio problems to me. Then, over the course of 16 years, it went from half a day a week, to a day a week and finally to full-time perio. You wouldn't do that now, but I had to as there was no such thing at the time. I had to do my own 'marketing' - giving talks on perio at every opportunity; writing perio articles for journals; asking perio questions at meetings. It was a long slow process of building a reputation. But I knew where I was going and where I wanted to be. I was convinced it was an investment in my own future.

\section{You are an expert dental witness - how did this come about?}

Sadly, there are patients who receive inadequate treatment, or the treatment just goes wrong and it's not anyone's fault. Those patients, if they have been damaged, are entitled to recompense. In order to get legal redress they need to go to a lawyer but the lawyer doesn't know anything about dentistry necessarily so he or she needs specialists in the field to help them. After you have been in practice for a while, one day someone will ask you for a report; for example a report on the injuries a patient may have sustained in an accident and the treatment required. That's how I got started as an expert witness. I happen to like writing and expressing my ideas in these reports. It requires another way of thinking and using my dental knowledge. 
I'm also basically a helping sort of person. Indeed, I am a dentist because I like helping people (I was helped out of pain myself by a kind dentist when I was little). I like that idea of being able to help patients who are troubled and also the lawyer to do their job.

Working with solicitors as a dental expert witness provides a new challenge. Quite often they ask different kinds of questions to my patients and colleagues. They ask me what is going to happen to the patient in the future and I have to give them some sort of educated guess.

In practice, running a business, I had to consider what would happen if I couldn't do clinical work, for example if I had an accident that damaged my hands or an eye. That was the other reason I developed the medico-legal side of things. It's reached the point now where I only do periodontics cases and I've got more than I can do. However, in over 15 years of doing it seriously I've never actually sat in court as an expert witness. They have all been settled outside of the courtroom.

\section{If you were Secretary of State for Health for a year, what would you do?}

I'd like to get the message across to the public that smoking and alcohol is really bad for you. A bit of alcohol is ok now and then but I see a lot of alcohol-related crime in my role as a magistrate. I also observe at close hand the damage alcohol does to health and relationships. My father smoked but I never did, and I'm very glad I didn't. However, I understand it's very hard for people who do smoke to stop. I'd like to find ways of getting that message across to people so they don't start smoking in the first place.

From a dental point of view the media campaign that the European Association of Periodontology is starting to make the public more aware of periodontal disease is on the button as far as I'm concerned. ${ }^{1}$ I'd like to raise awareness among the public that periodontal disease affects at least $10 \%$ of the population to the extent that their teeth might fall out. That is a lot of disease, discomfort and anguish.

We also need to raise awareness among the profession that periodontal disease is mostly treatable by a general dental practitioner. I don't think that the majority of the profession is convinced that it really works, though I know many dentists are aware. I would like to make sure that GDPs have the tools to treat periodontal disease; not necessarily the physical tools but the ability, knowledge, confidence and technique to do it for their patients on a consistent basis. In order to do that I'd have to do something else more fundamental, which is to make sure that when a dentist treats a patient for periodontitis on the NHS he or she is remunerated at the same level as for a filled tooth or crown fitting. Periodontitis does take time to treat. We are often talking about several hours of treatment and if the dentist isn't getting paid that much for doing it human nature says he or she won't do it. It's tough in practice to make time when there is no money. At the very least a dentist shouldn't be disadvantaged for treating periodontal disease. That is not the case at the moment in the current NHS contract.

\section{What do you do when you're not being a periodontist?}

I sit as a magistrate. It's a challenging position; listening to evidence, weighing it up to see who is telling you the truth, trying to sentence people in a way that will punish them for their misdeeds but perhaps help them have a better life in the future. Magistrates nowadays are encouraged to interact with defendants a lot more. We try to help them to avoid a criminal life in the future. I enjoy the challenge of it and it's a way of contributing to the wider community.

I've also been involved with music or performance of some kind for most of my life. I am part of an amateur drama group: the Jewish Theatre Group in Manchester. My favourite production with this group was a play called Ghetto, by Israeli playwright Joshua Sobol. It's about a theatre company formed in the Vilna Ghetto under German occupation in WWII. It was very powerful production which we put on in the week of Holocaust Memorial Day, so for our community it was very important. I've also just starting singing in the synagogue choir which is wonderful.

\section{What are you most proud of in your career to date?}

I'm still there after 40 years! I'm proud of that. I'm also very proud to be President of the BSP - I've been a member of it since not quite day one but pretty early on. I'm proud of the relationships I have with my patients and the successful practices I have had over the years.

However, what I am most proud of is the number of my employees that have gone on to further careers in dentistry; for example, people who started off with me as young junior dental nurses who are now dental hygienists in their own right. I know that I've helped them and given them self-confidence to move on in their career.

\section{Interview by Ruth Doherty}

1. Campaign launches in Manchester to raise awareness of the 'silent disease.' Br Dent J 2013; 214: 489. Online news story available at http://www.nature. com/bdj/journal/v214/n10/full/sj.bdj.2013.492.html (accessed July 2013). 